\title{
Penerapan Personal Hygiene Pada Penjamah Makanan di Pondok Pesantren Kecamatan Biring Kanaya Kota Makassar
}

\section{Application of Personal Hygiene To Food Handlers At The Boarding School Biringkanaya Sub District Makassar City}

\author{
Nildawati ${ }^{* a}$, Hasbi Ibrahim ${ }^{\mathrm{b}}$, Fatmawaty Mallapiang ${ }^{\mathrm{c}},{\text { Khansaa Afifah } \mathrm{M}^{\mathrm{d}} \text {, Emmi Bujawati }}^{\mathrm{e}}$ \\ ${ }^{\text {a,e }}$ Epidemiologi, Program Studi Kesehatan Masyarakat, Fakultas Kedokteran dan Ilmu Kesehatan, \\ Universitas Islam Negeri Alauddin Makassar, Indonesia \\ ${ }^{b, c, d}$ Kesehatan dan Keselamatan Kerja, Program Studi Kesehatan Masyarakat, Fakultas Kedokteran dan \\ Ilmu Kesehatan, Universitas Islam Negeri Alauddin Makassar, Indonesia
}

\section{A B S T R A C T/ A B S T R A K}

\begin{abstract}
Personal hygiene will have an impact on the food produced by a food handler. To carry out its functions, Islamic boarding schools have a food management system which is carried out by food handlers. This study aims to see the personal hygiene of food handlers at the Pondok Pesantren, Biringkanaya District, Makassar City. The research method used is descriptive research. The sampling method used was total sampling with a total of 30 samples. The results of the study prove that of the 30 respondents, $100 \%$ ingood category for the application of personal hygiene. The work period of less than or 5 years was 17 respondents $(56.7 \%)$ and respondents with a working period of more than 5 years were 13 respondents $(43.3 \%)$. Of the 30 respondents $(100 \%)$ only 1 respondent $(33 \%)$ had work experience as food handlers in another place, namely for 15 years at other Islamic boarding schools, 29 respondents $(96.7 \%)$ had no work experience as food handlers. The application of personal hygiene to food handlers is fairly good, all respondents have good personal hygiene, but the application of washing hands before and after work and after leaving the bathroom is not in accordance with good and correct hand washing procedures according to WHO or the Indonesian Ministry of Health, this is evidenced by the unavailability of hand washing facilities. Provision of education, media- related information personal hygiene should be performed periodically to increase awareness of food handlers, as well as providing training, SOP, APD, P3K box, and checks periodically.
\end{abstract}

Key words : Personal hygiene; Food Handlers; Islamic boarding school

\begin{abstract}
Personal hygiene akan berdampak pada makanan yang dihasilkan penjamah makanan. Untuk menjalankan fungsinya, pondok pesantren memiliki sistem penyelenggaraan makanan yang dilaksanakan oleh penjamah makanan. Penelitian ini bertujuan untuk melihat personal hygiene penjamah makanan di Pondok Pesantren Kecamatan Biringkanaya Kota Makassar. Metode penelitian yang digunakan adalah penelitian deskriptif. Metode pengambilan sampel yang digunakan adalah dengan total sampling dengan jumlah 30 sampel. Hasil penelitian membuktikan bahwa dari 30 responden $100 \%$ dengan kategori baik untuk penerapan personal hygiene. Masa kerja kurang dari atau 5 tahun sebanyak 17 responden (56.7\%) dan responden dengan masa kerja lebih dari 5 tahun sebanyak 13 responden (43.3\%). Dari 30 responden (100\%) hanya 1 responden (33\%) yang memiliki pengalaman kerja sebagai penjamah makanan di tempat lain yakni selama 15 tahun di pondok pesantren lain, 29 responden (96.7\%) tidak memiliki pengalaman kerja sebagai penjamah makanan. Penerapan Personal hygiene pada penjamah makanan terbilang baik, semua responden memiliki Personal hygiene dengan kategori baik, namun penerapan cuci tangan sebelum dan setelah bekerja dan setelah keluar dari kamar mandi tidak sesuai dengan tata cara cuci tangan yang baik dan benar menurut WHO ataupun Kementerian Kesehatan RI, hal ini dibuktikan dengan tidak tersedianya fasilitas cuci tangan. Pemberian edukasi, media informasi terkait personal higiene harus dilakukan secara berkala untuk meningkatkan kesadaran penjamah makanan, serta pengadaan pelatihan, SOP, APD, kotak P3K, dan pemeriksaan secara berkala.
\end{abstract}

Kata kunci : Personal hygiene; Penjamah Makanan; Pondok Pesantren 
Journal homepage: https://ejurnal.poltekkes-manado.ac.id/index.php/jkl PENDAHULUAN

Permasalahan kesehatan khususnya masalah personal hygiene dan sanitasi makanan merupakan masalah yang sangat kompleks. Kondisi personal hygiene penjamah makanan sangat mempengaruhi kebersihan dan kesehatan makanan yang diolahnya. Penjamah makanan yang tidak memperhatikan personal hygiene dapat menularkan berbagai macam penyakit. Salah satu perilaku higiene sanitasi untuk kesehatan makanan adalah dengan pengolahan dan penyajian makanan yang tidak sehat dari penjamah makanan. Beberapa kajian menunjukkan bahwa ditemukan 20 provinsi di Indonesia yang belum memenuhi syarat kesehatan yang meliputi mutu kesehatan, kebersihan dan keamanan sehingga akan berdampak munculnya penyakit. ${ }^{1}$ Ketidakmampuan dalam menjaga personal hygiene akan menyebabkan seseorang mudah mengalami infeksi dan penyakit kulit, karena berkaitan dengan bakteri, jamur dan virus. 2,3 Berdasarkan data Badan Kesehatan Dunia World Health Organization (WHO) pada tahun 2015 bahwa sebanyak 100.000 anak indonesia meninggal dunia karena penyakit yang berkaitan dengan Personal hygiene, salah satunya adalah diare. Anak usia sekolah yang menderita penyakit cacingan sebesar $40-60 \%$ dan infeksi saluran pernapasan akut sebesar 20\%. Semua masalah yang terjadi pada anak usia sekolah terjadi karena kurangnya pengetahuan, respon dan perilaku terhadap personal hygiene serta ada kontribusi dari penjamah atau pengolah makanan. 4,5

Perilaku yang baik harus diterapkan pada penjamah makanan sedini mungkin, terlebih perilaku yang berhubungan dengan personal hygiene. Buruknya kondisi personal hygiene penjamah makanan dapat menimbulkan peningkatan penyakit khususnya pada anak sekolah yang meliputi diare, infeksi saluran pernapasan akut (ISPA), Demam Berdarah Dengue (DBD), cacingan, infeksi tangan, infeksi mulut, campak, cacar air, gondong, infeksi mata dan infeksi telinga. ${ }^{6,7}$ Pemeliharaan personal hygiene penjamah makanan disekolah sangat menentukan status kesehatan anak sekolah. ${ }^{8}$ Sebagian besar dari total beban penyakit menular di seluruh dunia berkaitan dengan personal hygiene yaitu penyebaran patogen dari orang ke orang di dalam rumah tangga, sekolah maupun lingkungan lainnya. Penularan dari orang ke orang dapat terjadi melalui transfer langsung dari tangan ke mulut, melalui makanan, atau melalui transmisi karena partikel berventilasi aerasi akibat bersin, muntah atau diare cairan. ${ }^{9}$

Makanan merupakan salah satu kebutuhan primer dari setiap manusia. Tujuan manusia makan bukan hanya sekedar untuk mengatasi rasa lapar namun juga untuk memenuhi kebutuhan zat gizi yang terkandung dalam makanan tersebut. Jadi untuk menjaga zat gizi dalam makanan tidak hilang perlu diperhatikan pada saat mengolah bahan makanan menjadi suatu makanan yang sehat. ${ }^{10}$ Makanan yang sehat dan aman merupakan salah satu yang penting untuk meningkatkan derajat kesehatan oleh karena itu kualitas makanan yang baik secara bakteriologis, kimiawi, maupun fisik harus selalu diperhatikan. Penjamah makanan merupakan vektor yang dapat mencemari pangan baik cemaran fisik, kimia maupun biologi. Perilaku penjamah makanan yang tidak baik dapat meningkatkan resiko terjadinya kontaminasi bakteri pada makanan. ${ }^{11}$

Dalam proses pengolahan makanan, peran dari penjamah makanan sangatlah besar peranannya. Penjamah makanan mempunyai peluang untuk menularkan penyakit. Banyak infeksi yang ditularkan melalui penjamah makanan, antara lain Staphylococcus aureus ditularkan melalui hidung dan tenggorokan, kuman Clostridium perfringens, Streptococcus, Salmonella dapat ditularkan melalui kulit. Oleh sebab itu penjamah makanan harus selalu dalam keadaan sehat dan terampil. Perilaku penjamah makanan di antaranya dapat menentukan kualitas dari produk yang dihasilkan. Kasus penyakit karena makanan sering terjadi karena pada umumnya makanan dipersiapkan dan disajikan dengan hygiene dan sanitasi yang buruk. Kondisi tersebut disebabkan karena kurangnya pengetahuan dari penjual tentang hygiene dan sanitasi yang akan menyebabkan makanan mengandung bakteri dalam jumlah yang cukup banyak, mengandung racun bakteri atau mengandung bahan kimia berbahaya (terkontaminasi).

Penelitian epidemiologi menunjukkan bahwa makanan merupakan jalur penularan penyakit yang tak kalah pentingnya. ${ }^{12,13} \mathrm{Di}$ Amerika Serikat, 25\% dari semua penyebaran penyakit melalui makanan disebabkan pengolah makanan yang terinfeksi dan hygiene perorangan yang buruk. Faktor manusia dalam hal ini penjamah makanan mempunyai peran yang sangat besar dalam proses pengolahan makanan karena 
Journal homepage: https://ejurnal.poltekkes-manado.ac.id/index.php/jkl penjamah makanan dapat memindahkan bakteri pada makanan apabila mereka tidak menjaga higiene perorangan. 13,14,15 Faktor kebersihan penjamah atau pengelola makanan yang biasa disebut personal hygiene merupakan prosedur menjaga kebersihan dalam pengelolaan makanan yang aman dan sehat. ${ }^{16}$ Pengolahan makanan dilaksanakan di dapur, ditempat pengolahan ini terdapat banyak peralatan yang digunakan oleh penjamah makanan untuk membuat bahan makanan menjadi matang yang jika tidak dilakukan strelisasi, akan menimbulkan berbagai macam persoalan kesehatan. ${ }^{17}$

Berdasarkan penelitian sebelumnya diketahui bahwa responden memiliki tindakan personal hygiene yang buruk karena kurangnya pengetahuan dan kesadaran terhadap pentingnya tindakan Personal hygiene. Adapun responden memiliki pengetahuan yang baik terhadap personal hygiene, akan tetapi tidak menerapkan tindakan personal hygiene karena kurangnya kesadaran yang menyebabkan tindakan personal hygiene responden dalam kategori kurang. Hal ini sesuai dengan pendapat yang menyebutkan bahwa pengetahuan, sikap dan kesadaran seseorang dapat mempengaruhi praktik perilaku kesehatan. ${ }^{18}$ Penelitian lainnya yang dilakukan oleh Nathalia Vetri menunjukkan bahwa terdapat hubungan yang signifikan antara pengetahuan dan sikap terhadap personal hygiene yaitu dengan nilai $\mathrm{p}=0,000$. Hasil penelitian ini mengungkap $53,8 \%$ pengetahuan tentang personal hygiene tergolong rendah, 51,2\% sikap tentang Personal hygiene tergolong negatif, $55 \%$ dan personal hygiene tergolong buruk. ${ }^{19}$

\section{METODE}

Jenis penelitian yang digunakan adalah penelitian kuantitatif dengan pendekatan deskriptif observasional. Penelitian ini dilakukan di Pondok Pesantren yang ada di Kecamatan Biringkanaya Kota Makassar, yakni Pondok Pesantren Darul Arqam, Pondok Pesantren Darul
Aman, Pondok Pesantren Darun Nashar Timortimur, Pondok Pesantren Ummul Mukminin Putri, Pondok Pesantren Multidimensi AlFakhriyah, dan Pondok Pesantren Ulul Albab.Populasi dalam ini adalah semua pekerja dapur di Pondok Pesantren Kecamatan Biringkanaya Kota Makassar yakni sebanyak 6 Pondok Pesantren dengan jumlah sebanyak pekerja dapur 30 penjamah makanan (yang bertugas mempersiapkan, membersihkan, dan mengolah bahan dan peralatan) dengan rincian, Pondok Pesantren Darul Arqam dengan 6 penjamah makanan, Pondok Pesantran Darul Aman 9 penjamah makanan, Pondok Pesantren Darun Nashar Timor-timur 2 penjamah makanan, Pondok Pesantren Ummul Mukminin Putri 378 penjamah makanan, Pondok Pesantren Multidimensi Al-Fakhriyah 3 penjamah makanan, dan Pondok Pesantren Ulul Albab 3 penjamah makanan. Dalam penelitian ini menggunakan teknik pengambilan sampel secara total atau total sampling. total sampling yaitu teknik pengambilan sampel dimana jumlah sampel sama dengan populasi. Data dianalisis menggunakan program Microsoft Excel dan Statistic Package for Sosial Science (SPSS) yang mencakup Editing, Coding, Entry data, Cleaning dan Tabulating. Juga dilakukan Uji Validitas untuk mengukur sah atau valid tidaknya suatu butir pertanyaan. Serta uji Reliabilitas untuk menunjukkan tingkat konsistensi dan stabilitas dari data berupa skor hasil persepsi suatu variable baik variable bebas maupun terikat.

\section{HASIL}

\section{Penjamah makanan}

Dalam penelitian ini, yang menjadi responden adalah penjamah makanan yang mempersiapkan, membersihkan, dan mengolah bahan dan peralatan di pondok pesantren yang ada di Kecamatan Biringkanaya Kota Makassar. Adapun jumlah pekerja dapur dan responden dapat dilihat pada tabel 1 :

Tabel 1. Distribusi Responden Berdasarkan Jumlah Penjamah Makanan Pondok Pesantren Kecamatan Biringkanaya

\begin{tabular}{ccc}
\hline Pondok Pesantren & Pekerja Dapur (org) & Responden (org) \\
\hline Darul Arqam & 5 & 5 \\
Darul Aman & 13 & 8 \\
Ummul Mukminin & 9 & 8 \\
Darun Nashar & 3 & 2 \\
Al - Fakhriyah & 3 & 3 \\
Ulul Albab & 3 & 3 \\
\hline Total & 27 & 30 \\
\hline
\end{tabular}


Jurnal Kesehatan Lingkungan

Vol.10, No.2, Oktober 2020, pp. 68 - 75

ISSN 2615-188X(Online), ISSN 2089 - 0451(Print)

DOI: $10.47718 / \mathrm{jkl} . v 10 \mathrm{i} 2.1164$

Journal homepage: https://ejurnal.poltekkes-manado.ac.id/index.php/jkl

Tabel 1 menunjukkan bahwa dari 37

pekerja dapur di Pondok Pesantren Kecamatan

yang diambil sebagai responden penelitian.

Biringkanaya, terdapat 30 penjamah makanan

Adapun karakteristik responden sebagai berikut :

Tabel 2. Karakteristik Responden Penjamah Makanan Pondok Pesantren Kecamatan Biringkanaya

\begin{tabular}{|c|c|c|}
\hline Karakteristik & Frekuensi (n) & Persentase $(\%)$ \\
\hline \multicolumn{3}{|l|}{ Jenis Kelamin } \\
\hline Laki-laki & 2 & 6.7 \\
\hline Perempuan & 28 & 93.3 \\
\hline Total & 30 & 100 \\
\hline \multicolumn{3}{|l|}{ Umur } \\
\hline$<40$ & 10 & 33.3 \\
\hline$\geq 40$ & 20 & 66.7 \\
\hline Total & 30 & 100 \\
\hline \multicolumn{3}{|l|}{ Masa Kerja } \\
\hline$\leq 5$ & 17 & 56.7 \\
\hline$>5$ & 13 & 43.3 \\
\hline Total & 30 & 100 \\
\hline \multicolumn{3}{|l|}{ Pengalaman Kerja } \\
\hline Pekerja dapur di Pondok & 1 & 3.3 \\
\hline \multicolumn{3}{|l|}{ Pesantren Lain } \\
\hline Tidak ada & 29 & 96,7 \\
\hline Total & 30 & 100 \\
\hline
\end{tabular}

Sumber: Data primer 2018

Tabel 2 di menjelaskan bahwa dari 30 responden $(100 \%)$ yang berjenis kelamin perempuan sebanyak 28 responden $(93.3 \%)$ dan laki-laki sebanyak 2 responden (6.7\%). Responden berumur kurang dari 40 tahun sebanyak 10 responden $(33.3 \%)$ dan responden berumur lebih dari 40 tahun sebanyak 20 responden $(66.7 \%)$. Distribusi responden menurut masa kerja kurang dari atau 5 tahun sebanyak 17 responden $(56.7 \%)$ dan responden dengan masa kerja lebih dari 5 tahun sebanyak 13 responden $(43.3 \%)$.

Pengalaman kerja adalah pengalaman responden bekerja sebagai penjamah makanan di tempat lain sebelum memulai bekerja di tempat sekarag. Pengalaman kerja dalam tahun adalah kurun waktu yang dihabiskan responden mulai bekerja sampai berhenti bekerja. Distribusi responden menurut pengalaman kerja menunjukkan bahwa dari 30 responden $(100 \%)$ hanya 1 responden (33\%) yang memiliki pengalaman kerja sebagai penjamah makanan di tempat lain yakni selama 15 tahun di pondok pesantren lain, sedangkan 29 responden (96.7\%) tidak memiliki pengalaman kerja sebagai penjamah makanan.

Distribusi responden berdasarkan kategori nilai penerapan Personal hygiene penjamah makanan di Pondok Pesantren Kecamatan Biringkanaya adalah sebagai berikut:

Tabel 3. Distribusi Responden Berdasarkan Kategori Nilai Penerapan Personal Hygiene Penjamah Makanan di Pondok Pesantren Kecamatan Biringkanaya

\begin{tabular}{ccc}
\hline Kategori & Frekuensi (n) & Persentase $(\%)$ \\
\hline Baik & 30 & 100 \\
Cukup & 0 & 0 \\
Kurang & 0 & 0 \\
\hline Total & 30 & 100
\end{tabular}

Sumber: Data primer 2018 
Tabel 3 menunjukkan bahwa dari 30 responden (100\%), semua responden (100\%) mendapatkan nilai dengan kategori baik untuk penerapan Personal hygiene . Responden mengutarakan bahwa kebiasaan menjaga kebersihan diri merupakan hal dasar yang didapatkan selama bekerja di lingkungan pondok pesantren. Adapun mandi 2 kali sehari, menggosok gigi 2 kali sehari, mengganti pakaian setiap hari, dan keramas sekali sepekan sesuai dengan persentase berturut-turut menunjukkan lebih dari $70 \%$ responden mengatakan selalu melakukannya. Responden mengutarakan bahwa terkadang mereka mandi lebih dari 2 kali sehari dan keramas hampir setiap hari dikarenakan kondisi tempat kerja yang sangat panas.

\section{PEMBAHASAN}

Penjamah Makanan adalah orang yang secara langsung berhubungan dengan makanan dan peralatan mulai dari tahap persiapan, pembersihan, pengolahan, pengangkutan sampai dengan penyajian. Berdasarkan tabel 1 menunjukkan terdapat 37 orang penjamah makanan di Pondok Pesantren Kecamatan Biringkanaya Kota Makassar, meski demikian yang menjadi reponden sebanyak 30 orang. Hal ini dikarenakan 7 orang lainnya tidak sesuai dengan karakteristik yang dikehendaki peneliti, yakni penjamah makanan yang mempersiapkan, membersihkan, dan mengolah bahan dan peralatan, 7 orang lainnya bertugasa untuk menentukan menu, mengangkut, dan membagikan makanan. Berdasarkan tabel 2 menunjukkan 93.3\% responden berjenis kelamin perempuan. Responden mengutarakan perempuan lebih cocok sebagai pekerja dapur dengan alasan pekerjaan dapur memang merupakan pekerjaan perempuan. Hal ini tidak sejalan dengan penelitian oleh Ugur (2013) dan Salleh (2017) yang menunjukkan prevalensi pekerja dapur laki-laki lebih banyak daripada perempuan yakni sebanyak $54 \%$ dan $61 \%$ berturut-turut. Tanggapan pekerjaan dapur merupakan pekerjaan perempuan adalah budaya yang dianut sebagian besar mesyarakat Indonesia. 20,21

Personal hygiene atau kebersihan diri adalah suatu tindakan memelihara kebersihan dan kesehatan diri untuk kesejahteraan fisik dan psikis. Perilaku Personal hygiene adalah suatu pemahaman, sikap dan praktik yang dilakukan oleh seseorang untuk meningkatkan derajat kesehatan, memelihara kebersihan diri, meningkatkan rasa percaya diri, menciptakan keindahan dan mencegah timbulnya penyakit. ${ }^{22}$ Meskipun secara keseluruhan, penerapan Personal hygiene terbilang baik, namun penerapan cuci tangan sebelum, setelah bekerja dan setelah buang air besar masih harus ditindaklanjuti. Berdasarkan hasil penelitian menunjukkan bahwa lebih dari $90 \%$ responden mengatakan selalu melakukannya, namun dalam pengaplikasiannya tidak sesuai dengan standar Kementerian Kesehatan RI, bahwa mencuci tangan harus menggunakan sabun di bawah air mengalir selama kurang lebih 15-20 detik.

Hasil observasi peneliti, responden mengatakan bahwa mereka telah mencuci tangan jika tangan mereka telah basah oleh air atau telah dibilas oleh air. Sedangkan fasilitas mencuci tangan seperti westafel memang tidak disediakan oleh pihak pondok pesantren untuk para penjamah makanan. Adapun kebiasaan mengobrol sambil bekerja merupakan hal biasa bagi para responden, $80 \%$ responden selalu mengobrol sambil bekerja. Pemberian eduksi untuk tentang tata cara mencuci tangan dengan benar harus dilakukan oleh pihak pondok pesantren untuk menghindari kontaminasi terhadap makanan. Pemberian edukasi harus disertai dengan pengadaan poster dan lainnya yang berisi informasi mengenai pentingnya menjaga kebersihan diri dan tata cara menjaga kebersihan diri yang benar. ${ }^{23}$ Kondisi Personal hygiene dapat dipengaruhi oleh berbagai faktor, diantaranya adalah pengetahuan, sikap, ketersediaan sarana prasarana kebersihan diri dan juga akses terhadap media-media kesehatan.

Berbagai penelitian menunjukkan adanya hubungan antara pengetahuan dengan Personal hygiene. Penelitian yang dilakukan Prasetyo (2015) diketahui bahwa pengetahuan Personal hygiene ada hubungan antara tingkat pengetahuan dengan Personal hygiene. Hal ini menunjukkah bahwa pengetahuan responden yang baik mempengaruhi Personal hygiene responden. ${ }^{24}$ Penelitian lainnya yang dilakukan oleh Antoni pada tahun 2013 didapatkan hasil tindakan Personal hygiene yang kurang baik lebih banyak terjadi pada responden yang memiliki sikap negatif $(53,3 \%)$ dibandingkan dengan responden yang memiliki sikap positif $(5,6 \%)$, dan ada hubungan antara sikap dengan tindakan Personal 
Journal homepage: https://ejurnal.poltekkes-manado.ac.id/index.php/jkl hygiene. Selain pengetahuan dan sikap yang berhubungan secara signifikan dengan Personal hygiene anak pada penelitian sebelumnya, media promosi kesehatan juga diperkirakan menjadi salah satu faktor yang dapat mempengaruhi pengetahuan anak tentang Personal hygiene. Menurut Pertiwi dan Annissa (2018) menyebutkan bahwa media promosi kesehatan yang terdapat di lingkungan tempat bekerja tersedia sebanyak $65 \%$ dalam bentuk poster kebersihan yang jumlahnya masih sangat terbatas (Pertiwi, Annissa, 2018).

Keterbatasan media promosi kesehatan tersebut dapat berdampak pada tingkat pengetahuan siswa mengenai Personal hygiene, sehingga perlu adanya peningkatan penyuluhan maupun edukasi. Peningkatan pengetahuan dapat dilakukan melalui berbagai cara, diantaranya adalah dengan cara edukasi dan sosialisasi baik melalui media cetak maupun non cetak. Saat ini penggunaan media non cetak seperti media sosial dianggap sangat efektif untuk menyampaikan pesan-pesan kesehatan. ${ }^{25,} 26$ Selain itu penelitian yang dilakukan oleh suherman, dkk menunjukkan bahwa kebiasaan cuci tangan mempunyai hubungan yang signifikan dengan kejadian diare pada anak sekolah. ${ }^{27}$

Menurut Fatmawati, dkk. (2013), salah satu prinsip dasar penyelenggaraan makanan institusi adalah penyelenggaraan makanan yang menerapkan higiene dan sanitasi sesuai ketentuan yang berlaku. Salah satu faktor yang mendukung prinsip higiene dan sanitasi penyelenggaraan makanan adalah faktor kebersihan penjamah makanan atau higiene perorangan. Higiene perorangan merupakan perilaku bersih, aman dan sehat penjamah makanan untuk mencegah terjadinya kontaminasi pada makanan mulai dari persiapan bahan makanan sampai penyajian makanan. Beberapa prosedur penting bagi penjamah makanan, yaitu cuci tangan sebelum dan sesudah memegang bahan makanan, memakai alat pelindung diri yang lengkap dan kebersihan serta kesehatan diri. ${ }^{28}$.

Terkait pengetahuan penjamaah makanan di ketahui bahwa pengetahuan bukan merupakan satu-satunya faktor yang dapat memengaruhi sikap, namun pengetahuan adalah salah satu faktor yang dapat memengaruhi higiene perorangan penjamah makanan. 29 Hasil penelitian Erruliya (2008), yang menyatakan bahwa terdapat korelasi yang positif antara pengetahuan dengan perilaku. Pengetahuan penjamah makanan yang baik mendukung sikap positif agar dapat menerapkan prinsip higiene dan sanitasi penyelenggaraan makanan dengan baik dan benar. Hasil penelitian Sanlier dan Konaklioglu (2012), juga menyatakan bahwa terdapat korelasi yang kuat antara pengetahuan keamanan pangan dengan perilaku penjamah makanan $(\mathrm{r}=0,406 . \mathrm{p}<0,01) .{ }^{30,31}$ Berdasarkan hasil penelitian Handayani dkk., (2015), menyatakan bahwa penjamah makanan yang memiliki sikap baik cenderung memiliki pengetahuan yang baik. Demikian juga menurut Mangunsong dkk., (2015), semakin baik pengetahuan higiene dan sanitasi, semakin baik pula sikap siswa dalam melaksanakan praktek higiene dan sanitasi pada praktek mengolah kue. $32,33,34$.

Berdasarkan peraturan perundangundangan hygiene dan sanitasi makanan, Kepmenkes nomor 942/Menkes/SK/VII/2003 tentang pedoman persyaratan hygiene sanitasi makanan jajanan, penjamah makanan adalah orang yang secara langsung berhubungan dengan makanan dan peralatan mulai dari tahap persiapan, pembersihan, pengolahan, pengangkutan sampai dengan penyajian. Hygiene tenaga penjamah makanan dengan tujuan untuk mewujudkan penyehatan perorangan yang layak dalam penyelenggaraan makanan, diperlukan tenaga penjamah yang memenuhi syarat sebagai berikut tidak menderita penyakit mudah menular, menutup luka (pada luka terbuka/bisul atau luka lainnya), memakai celemek dan tutup kepala, mencuci tangan setiap kali hendak menangani makanan, menjamah makanan harus memakai alat/ perlengkapan atau dengan alas tangan, tidak sambil merokok, menggaruk anggota badan (telinga, hidung, mulut, atau bagian lainnya), tidak batuk atau bersin dihadapan makanan jajanan yang disajikan dan atau tanpa menutup mulut atau hidung. ${ }^{35}$.

Hygiene dan sanitasi tidak dapat dipisahkan satu dengan yang lain karena erat kaitannya. Misalnya hygiene sudah baik karena mau mencuci tangan, tetapi sanitasinya tidak mendukung karena tidak cukup tersedia air bersih, maka mencuci tangan tidak sempurna. Higiene dan sanitasi merupakan hal yang penting dalam menentukan kualitas makanan dimana Escherichia coli sebagai salah satu indikator terjadinya pencemaran makanan yang dapat menyebabkan penyakit akibat makanan (food borne diseases). E.coli dalam makanan dan minuman merupakan 
Jurnal Kesehatan Lingkungan

Vol.10, No.2, Oktober 2020, pp. 68 - 75

ISSN 2615-188X(Online), ISSN 2089 - 0451(Print)

DOI: $10.47718 /$ jkl.v10i2.1164

Journal homepage: https://ejurnal.poltekkes-manado.ac.id/index.php/jkl

indikator terjadinya kontaminasi akibat penanganan makanan dan minuman yang kurang baik. Minimnya pengetahuan para penjamah makanan mengenai cara mengelola makanan dan minuman yang sehat dan aman, menambah besar resiko kontaminasi makanan dan minuman yang dijajakannya. ${ }^{36}$

\section{KESIMPULAN}

Penerapan personal hygiene penjamah makanan terbilang baik, semua responden memiliki personal hygiene dengan kategori baik. Namun penerapan cuci tangan sebelum dan setelah bekerja dan setelah keluar dari kamar mandi tidak sesuai dengan tata cara cuci tangan yang baik dan benar menurut WHO ataupun Kementerian Kesehatan RI. Hal ini juga diperparah dengan tidak tersedianya fasilitas cuci tangan yang baik.

\section{SARAN}

Diharapkan pondok pesantren dapat memberikan pelatihan, edukasi, dan/atau informasi yang berkelanjutan terkait personal hygiene kepada seluruh penjamah makanan atau media poster terkait personal hygiene penjamah makanan .

\section{DAFTAR PUSTAKA}

1. Dewi Kharsima A. Tingkat Pengetahuan Dan Perilaku Penerapan Personal Hygiene Penjamah Makakan Di Pasar Senggol Tabanan Tahun 2017. Politeknik Kesehatan Denpasar Jurusan Kesehatan Lingkungan Program Studi Diploma III. 2017.

2. Minartami EJ dan LA. Jenis Kelamin, Personal Hygiene, dan Sanitasi Lingkungan dengan Kejadian Scabies pada Santri di Pondok Pesantren Darul Ma'arif Kabupaten Sintang. J Mhs dan Penelit Kesehat. 2017 : 4(1).

http://openjurnal.unmuhpnk.ac.id/index.php/JJ $\mathrm{UM} /$ article/view/844

3. Mukaromah S, Menge Katharina. Pendidikan Kesehatan (Personal Hygiene) Terhadap Tingkat Pengetahuan, Sikapdan Tindakan Personalhygiene Anak Usia Sekolah. Jurnal Medika Karya Ilmiah Kesehatan 2020 : 5(1) ISSN : 2654 - 945X (Online), 2541-4615 
Teknik Pencucian Alat Makan, Personal Hygiene Terhadap Kontaminasi Bakteri pada Alat Makan. Jurnal Endurance 2017 :
(2) 3
376-382.

https://www.researchgate.net/publication/3 20570291.

16. Haruyama Y, Matsuzuki H, Tomita S, et al. Burn and cut injuries related to job stress among kitchen workers in Japan. Ind Health. 2014 : 52 (2) : 113120. doi:10.2486/indhealth.2013-0143. https://pubmed.ncbi.nlm.nih.gov/2442951 $\underline{81}$

17. Fatmawati, S., dkk. Perilaku Hygiene Pengolah Makanan Berdasarkan Pengetahuan Tentang Higiene Mengolah Makanan Dalam Penyelenggaraan Makanan Di Pusat Pendidikan Dan Latihan Olahraga Pelajar Jawa Tengah. Jurnal Gizi Universitas Muhammadiyah Semarang 2013 : (2) 2 : 30-38. https://jurnal.unimus.ac.id/index.php/jgizi/ article/view/1032

18. Narida, A. Perilaku Sanitasi, Higiene dan Keselamatan Kesehatan Kerja (K3) dalam Praktik Masakan Indonesia Siswa Program Keahlian Tata Boga Smk Negeri 6 Yogyakarta Tahun Pelajaran 2013-2014. Skripsi. Yogyakarta: Universitas Negeri Yogyakarta. 2014.

19. Ghanim M, Dash N, Abdullah B, Issa H, Albarazi R, Saheli Z Al. Knowledge and Practice of Personal Hygiene among Primary School Students in Sharjah-UAE. J Heal Sci. 2016 : 6(5) : 67-73. http://article.sapub.org/10.5923.j.health.20160 605.01.html

20. Nathalia Vetri, Vakol Gito. Hubungan pengetahuan dan sikap murid SD terhadap personal higiene. Jurnal Akademika $\begin{array}{lllll}\text { Baiturrahim } 2019 \quad \text { : } & 8 & \text { (1). }\end{array}$ http://jab.stikba.ac.id/index .php/jab/article /download/ 106/78

21. Salleh, et al. Preliminary Study of Musculoskeletal Complaints and Ergonomic Risk Factors among Catering Workers. Asia Pacific Environmental and Occupational Health Journal 2017 : (3) 1 39

http://apeohjournal.org/index.php/v/article /download/43/56

22. Ugur, et al. "Occupational Allergic
Diseases in Kitchen and Health Care Workers : An Underestimated Health Issue". BioMed Research International 20133 (1): : 4 - 7. https://www.ncbi. nlm.nih.gov/pmc/articles/PMC3844187/

23. Rianti, E. Personal Higiene dalam Perspektif Islam. Cat. 1; Tanggerang selatan: Cinta Buku Media, 2017.

24. Kementerian Pendidikan dan Kebudayaan. Sanitasi, Hygiene, dan Keselamatan dan Kesehatan Kerja bidang Makanan II. Cet. I; Depok: Kementerian Pendidikan dan Kebudayaan, 2013.

25. Prasetyo. Hubungan Tingkat Pengetahuan Dan Dukungan Keluarga Dengan Personal Hygiene Pada Siswa Di Sdn Panjang Wetan IV Kecamatan Pekalongan Utara Kota Pekalongan. Fikkes Jurnal Keperawatan 2015 : (8) 1 https://jurnal.unimus.ac.id/index.php/FIKk eS/article/download/1902/1944

26. Antoni, A. Analisis Pengetahuan dan Sikap Murid SD Tentang Kebersihan Diri di SD Negeri No. 55 Air Pacah Padang. Padang : Jurnal Kesehatan 2015 : 2 (1). http://ejournal. stikesyarsi.ac.id/ index.php/JAV1N1/article/view/45

27. Pertiwi, Wiwik Eko. Annissa. Ketersediaan Media Promosi Kesehatan. Laporan Penelitian. STIKes Faletehan Serang. 2018.

28. Suherman, Qurota F, Aini. Analisis Kejadian diare pada siswa di SD Negeri Pamulang 02 Kecamatan Pamulang. Jurnal Kedokteran dan Kesehatan 2019 : 15 (2) https://jurnal.umj.ac.id /index.php/JKK/ article/view/4175/3266.

29. Fatmawati, S., Rosidi, A., Handasari, E. Perilaku higiene pengolah makanan berdasarkan pengetahuan tentang higiene mengolah makanan dalam penyelenggaraan makanan di Pusat Pendidikan dan Latihan Olahraga Pelajar Jawa Tengah. Jurnal Gizi Universitas Muhammadiyah Semarang, 2013 : 2(2) : 30-38.

https://jurnal.unimus.ac.id/index.php/jgizi/ article/view/1032

30. Miranti A E, Adi C A. Hubungan Pengetahuan Dengan Sikap Dan Higiene Perorangan (Personal Hygiene) Penjamah Makanan Pada Penyelenggaraan Makanan Asrama Putri. Jurnal media gizi indoneia 
Journal homepage: https://ejurnal.poltekkes-manado.ac.id/index.php/jkl $2016: 11$ (2) $\quad$. $\quad$ https://ejournal.unair.ac.id/MGI/article/view/7435/ $\underline{0}$

31. Erruliya. Faktor yang mempengaruhi praktek hygiene dan sanitasi penjamah makanan pada usaha jasaboga Dharma Wanita RSU Dr. Soedono Madiun. Universitas Airlangga, Surabaya. 2018.

32. Sanlier, N., and Konaklioglu, E.. Food safety knowledge, attitude and food handling practices of students. British Food Journal, 2012 : 114(4) : 469- 480. Diakses dari http://emeraldinsight.com.

33. Handayani, N.M.A., Adhi, K.T., Duarsa, D.P. Faktor yang mempengaruhi perilaku penjamah makanan dalam penerapan cara pengolahan pangan yang baik pada industri rumah tangga di Kabupaten Karangasem. Public Health and Preventive Medicine Archive, 2015 : 3(2) : 194-202. https://ejournal.unair.ac.id/MGI/article/view/7435/0
34. Mangunsong, S. W. A., Yusuf, L., Syarif, W. Hubungan pengetahuan hygiene sanitasi dengan sikap siswa pada praktek mengolah kue indonesia di Workshop SMKN 3 Muara Bungo. E-Journal Home Economic and Tourism 2015: 8(1) : 1-16. http://ejournal.unp.ac.id/index. php/jhet/article/view/ 4532/3579

35. Yulianto. Penerapan Standard Hygiene Dan Sanitasi Dalam Meningkatkan Kualitas Makanan di Food and Beverage Departemen, Jurnal Khasanah Ilmu 2015 : 6 (2). https://ejournal.bsi.ac.id/ ejurnal/ index.php/khasanah/article/view/484

36. Riyan. Penyuluhan Hygiene Sanitasi Makanan dan Minuman, Serta Kualitas Makanan yg Dijajakan Pedagang di Lingkungan SDN Kota Samarinda, Jurnal Kesehatan Masyarakat 2014: 10

https://journal.unnes.ac.id/nju/index.php/kema s/article/view/3071 